\title{
Sweet Potato Flour as a Replacement for Ground Corn as an Energetic Concentrate
}

\author{
Marilisa Mibach ${ }^{1}$ (D) Claudia Faccio Demarco' ${ }^{1}$ (D) Antonio Amaral Barbosa ${ }^{1}$ (D) \\ Lisandre de Oliveira ${ }^{2}$ (D) Marcio Nunes Corrêa ${ }^{1}$ (D) Francisco Augusto Burkert Del Pino ${ }^{1}$ (D) \\ Viviane Rohrig Rabassa ${ }^{1}$ (D) Eduardo Schmitt $^{1}$ (D) \\ Gilberto Vilmar Kozloski ${ }^{3}$ (D) Cassio Cassal Brauner ${ }^{* *}$ (D)
}

${ }^{1}$ Núcleo de Pesquisa, Ensino e Extensão em Pecuária (NUPEEC), Universidade Federal de Pelotas (UFPel), 96160-000, Pelotas, RS, Brasil. E-mail: cassiocb@gmail.com. "Corresponding author.

${ }^{2}$ Instituto Federal Sul Rio-grandense (IFSul), Pelotas, RS, Brasil.

${ }^{3}$ Programa de Pós-graduação em Zootecnia, Universidade Federal de Santa Maria (UFSM), Santa Maria, RS, Brasil.

\begin{abstract}
This study evaluated the effects of different levels of substitution of ground corn by sweet potato flour on intake, digestibility, microbial protein synthesis and total Nitrogen $(N)$ retention in sheep fed mixed diets based on corn silage. Eight castrated male sheep were used, kept in metabolic cages. The animals received fixed proportions of oat hay, corn silage and soybean meal. The control group (0\%) received only ground corn, while the other groups received different levels of inclusion of sweet potato flour (SPF) to replace ground corn, in the proportions of $33 \%, 66 \%$, and $100 \%$. The $0 \%$ and $33 \%$ groups had lower neutral detergent fiber (NDF) intake than the $66 \%$ and $100 \%$ groups. There was a trend $(P=0.07)$ of effect of treatments on crude protein $(C P)$ intake with a significant positive linear effect $(P=0.03)$. There was a trend $(P=0.07)$ for treatment effects in $N$ intake with a significant positive linear effect $(P=0.03)$. The other parameters as urine $N$ excretion $(P=0.91)$ and feces $N$ excretion $(P=0.16)$ were not affected by the replacement of ground corn by $S P F$. Moreover, there was no effect on $N$ retention $(P=0.43)$ and on efficiency of $N$ use $(P=0.69)$. Adding SPF to a diet instead of corn did not alter the microbial protein parameters. The inclusion of sweet potato flour did not cause changes in the protein metabolism of animals, suggesting it can be used instead of corn.

Key words: alternative feed, carbohydrate, faecal, metabolism.
\end{abstract}

Utilização de farinha de batata-doce como substituto ao milho moído como concentrado energético

RESUMO: O objetivo desse estudo foi avaliar os efeitos dos diferentes níveis de substituição de milho moído por farinha de batata-doce na ingestão, digestibilidade, síntese de proteina microbiana e a retenção de Nitrogênio $(N)$ em ovinos alimentados por dietas com base em silagem de milho. Foram utilizados oito ovinos machos castrados, mantidos em gaiolas metabólicas, divididos em quatro grupos no quadrado latino 4 $x 4$, totalizando quatro periodos de 15 dias cada. Os animais receberam proporções fixas de feno de aveia, silagem de milho e farelo de soja. O grupo controle (0\%) recebeu apenas milho moido, enquanto os outros grupos receberam diferentes niveis de inclusão de farinha de batata doce (FBD) em substituição ao milho moído, nas proporções de 33\%, 66\% e 100\%. Amostras de alimentos e sobras foram coletadas para avaliação do consumo e análise bromatológica. A urina foi coletada para avaliação da síntese proteica microbiana através dos derivados da purina (DP). As fezes foram coletadas para análise e estimativa da digestibilidade. Os grupos de 0\% e 33\% apresentaram menor consumo de fibra em detergente neutro (FDN) do que os grupos de 66\% e 100\%. Houve uma tendência $(P=0,07)$ de efeito dos tratamentos na ingestão de proteína bruta $(P B)$ com efeito linear positivo significativo $(P=0,03)$. Houve uma tendência $(P=0,07)$ para os efeitos do tratamento na ingestão de $N$ com um efeito linear positivo significativo $(P=0,03)$. Os demais parâmetros como excreção de $N$ na urina $(P$ $=0,91)$ e excreção de $N$ nas fezes $(P=0,16)$ não foram afetados pela substituição do milho moído pela FBD. Além disso, não houve efeito na retenção de $N(P=0,43)$ e na eficiência do uso de $N(P=0,69)$. A adição de FBD a uma dieta em vez de milho não alterou os parâmetros das proteinas microbianas. A inclusão de farinha de batata-doce não causou alterações no metabolismo proteico dos animais, sugerindo que pode ser utilizada no lugar do milho.

Palavras-chave: alimentos alternativos, carboidrato, fecal, metabolismo.

\section{INTRODUCTION}

Supplementation with non-fibrous carbohydrate (NFC) in ruminant diets is often used to achieve energy requirement for maintenance and even the highest productivity (CATON \& DHUYVETTER, 1997). Starch is the most used NFC in ruminant nutrition, is a polysaccharide reported in different types of plants, and it is composed of two types of molecules: amylose and amylopectin (SANTANA \& MEIRELES, 2014). Along with barley and wheat, corn is one of the most used sources of starch in livestock systems (DECKARDT et al., 2013) in its different presentations (ground grain, whole grain, and moisture grain). PASSETTI et al. (2016) conducted a study in Brazilian intensive 
system farms and related that all of them use corn silage and/or ground corn on cows' diets.

Among feed that are used in ruminant diets, sweet potato (Ipomoea batatas), is a rich starch tuber (ROSTAGNO, 2005). In particular, the use of sweet potatoes that are not directed to human market, remain on the soil after harvesting and can develop fungi and deteriorate the soil. It is considered a rustic crop because it is resistant to various pests and grows in degraded soils. Approximately $95 \%$ of the sweet potato produced in the world comes from developing countries, making this vegetable an important ally in the economic and social development of emerging countries (VELARDE et al., 2015).

Corn and sweet potato have similar content of starch $-70 \%$ vs. $75 \%$, respectively. Corn starch is formed by $30 \%$ of amylose and $70 \%$ of amylopectin, while sweet potato starch is formed by $28 \%$ of amylose and $72 \%$ of amylopectin (GÓMEZ et al., 2016). Although, similar to each other, differences in ruminal fermentation between types of starch from vary sources may happen. However, there is a lack of information about the possibility of inclusion of SPF in ruminant feeding.

The aim of this research was to evaluate the extent to which different levels of substitution of ground corn by sweet potato flour can be performed without damage to ruminal metabolism and diet utilization in lambs receiving mixed diets based on corn silage.

\section{MATERIALS AND METHODS}

All the procedures were approved by the Ethics Committee on Animal Experimentation (under n. 3255). A metabolism trial was conducted using eight Corriedale male lambs $(19.4 \pm 3.6 \mathrm{~kg}$ body weight (BW) measured in the first day of adaptation period), between 10 and 12 months, in a double 4 X 4 Latin Square design. The experimental periods were composed by 15 days, in which 10 of them were for adaptation to the diets, according FARENZENA et al. (2017) and the last 5 days for samples collection. Lambs were kept in metabolic cages $(1.10 \mathrm{~m}$ long x $0.50 \mathrm{~m}$ wide $\times 0.90 \mathrm{~m}$ high), the animals showed no signed of discomfort, receiving water ad libitum. Before the beginning of the trial, the animals were submitted to an 18-day period for gradual inclusion of concentrate feedstuff in the diet and adaptation to the metabolic cages.

Diets were calculated individually, in order to meet the daily supply of dry matter (DM) at $3 \%$ of BW (NRC, 2007). The DMI level was adjusted on a weekly basis as the BW changed. Total diet was divided into 3 portions, offered at 8:30 a.m., 1 p.m. and 5 p.m. Total mixed ration (TMR) was composed by fixed proportions of oat hay, corn silage, and soybean meal (Table 1, Table 2). Also, in table 1 is demonstrated proportions of the ingredients and the chemical composition in different treatments. Concentrate feedstuff varied in the different treatments wherein the Control group ( $0 \% \mathrm{SPF}$ ) received only ground corn as an energetic concentrate, while the others three groups received different levels of SPF in replacement of ground corn $(33 \%, 66 \%$ and $100 \%$ SPF). Sweet potato varieties used was "Cabeluda". Urea was added in order to keep diets isonitrogenated and all diets were isoenergetic.

Collection of urine and feces were made in the morning period, before the first meal of the day. Corn silage and oat hay samples were collected at first and last day of each collection period. Soybean meal,

Table 1 - Nutritional composition of the compounds used in diets.

\begin{tabular}{|c|c|c|c|c|c|}
\hline Compound & $\mathrm{DM}$ & OM & Ash & $\mathrm{CP}$ & NDF \\
\hline Oat hay & $87.1 \pm 0.42$ & $86.8 \pm 2.20$ & $13.2 \pm 2.21$ & $11.2 \pm 1.54$ & $66.2 \pm 1.63$ \\
\hline Corn silage & $22.7 \pm 1.85$ & $94.4 \pm 1.24$ & $5.6 \pm 1.24$ & $6.4 \pm 0.77$ & $61.9 \pm 2.84$ \\
\hline Soybean meal & $88.3 \pm 2.23$ & $89.3 \pm 3.68$ & $10.7 \pm 3.67$ & $49.3 \pm 7.96$ & $23.8 \pm 7.23$ \\
\hline Ground corn & $88.1 \pm 0.88$ & $93.2 \pm 3.53$ & $6.8 \pm 3.54$ & $11.8 \pm 3.12$ & $19.6 \pm 2.60$ \\
\hline Sweet potato flour & $90.6 \pm 1.87$ & $96.5 \pm 0.83$ & $3.6 \pm 0.84$ & $7.5 \pm 0.51$ & $8.5 \pm 3.41$ \\
\hline
\end{tabular}

${ }^{1}$ Nutritional composition: values in $\%$ of $\mathrm{DM} \pm$ standard deviation. Values are presented as mean values of experimental periods. DM: dry matter; OM: organic matter; CP: crude protein; NDF: neutral detergent fiber. 
Table 2 - Ingredient proportions and chemical composition of experimental diets.

\begin{tabular}{|c|c|c|c|c|c|}
\hline \multirow[b]{2}{*}{ Item } & \multicolumn{4}{|c|}{ 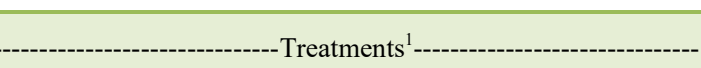 } & \multirow[t]{2}{*}{ SD } \\
\hline & $0 \%$ & $33 \%$ & $66 \%$ & $100 \%$ & \\
\hline \multicolumn{6}{|c|}{ - } \\
\hline Oat hay & 21 & 21 & 21 & 21 & - \\
\hline Corn silage & 21 & 21 & 21 & 21 & - \\
\hline Soybeanmeal & 18 & 18 & 18 & 18 & - \\
\hline Ground corn & 40 & 27 & 13 & - & - \\
\hline Sweet potato flour & - & 13 & 27 & 40 & - \\
\hline Urea & - & 0.14 & 0.26 & 0.39 & - \\
\hline \multicolumn{6}{|c|}{ 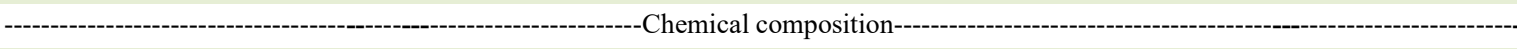 } \\
\hline $\mathrm{DM}(\%)$ & 73.8 & 74.1 & 74.5 & 74.8 & 0.33 \\
\hline Ash $(\%$ of DM) & 7.93 & 7.58 & 7.18 & 6.93 & 1.24 \\
\hline OM ( $\%$ of DM) & 92.1 & 92.4 & 92.8 & 93.1 & 1.24 \\
\hline NDF $(\%$ of DM) & 39.9 & 38.3 & 36.7 & 35.2 & 1.22 \\
\hline $\mathrm{CP}(\%$ of $\mathrm{DM})$ & 17.2 & 16.9 & 16.2 & 16.3 & 1.83 \\
\hline
\end{tabular}

${ }^{1}$ Treatments: replacement levels of ground corn by sweet potato flour as an energetic concentrate. DM: dry matter; OM: organic matter; NDF: neutral detergent fiber; $\mathrm{CP}$ : crude protein; SD: standard deviation.

ground corn, and SPF were collected once at each collection period. The refusals were weighed once a day, in every day of the experiment, for consumption measurements. Samples of feedstuffs and orts were collected, dried at $55^{\circ} \mathrm{C}$ for 72 hours, and stored until further analysis.

Urine was collected daily during the collection period, in buckets containing $100 \mathrm{~mL}$ of $7.2 \mathrm{~N} \mathrm{H}_{2} \mathrm{SO}_{4}$. Volume was measured, and a sample of $10 \mathrm{~mL}$ was stored frozen $\left(-80^{\circ} \mathrm{C}\right)$, until later analysis. At the end of the experiment, one pool by animal by period was composed, with a proportional amount of excreted urine in each day of collection.

Total excreted feces were collected every day of collection period and stored frozen in identified buckets. At the end of the collection period, the total amount was weighed and recorded. Total excreted feces were homogenized manually, and two samples of $300 \mathrm{~g}$ each were separated, dried at $55^{\circ} \mathrm{C}$ for 72 hours, and stored until analysis.

Samples of offered feed, orts and feces were analyzed for dry matter (DM), ash, organic matter $(\mathrm{OM})$, total Nitrogen $(\mathrm{N})$ and neutral detergent fiber (NDF). DM was determined by drying at 105 ${ }^{\circ} \mathrm{C}$ for 24 hours. Ash was determined by combusting at $600{ }^{\circ} \mathrm{C}$ for 4 hours. OM was determined by the mass difference between DM and ash. Total $\mathrm{N}$ was assayed by Kjeldahl method (method 984.13, AOAC,
1997). NDF content was determined based on the procedures described by MERTENS (2002), with use of heat-stable $\alpha$-amylase, except the samples that were weighed into polyester filter bags (porosity of $16 \mu \mathrm{m}$ ), and treated with neutral detergent in an autoclave at $110^{\circ} \mathrm{C}$ for 40 minutes (SENGER et al., 2008).

Total $\mathrm{N}$ of urine samples was determined by the same method previously described for feeds and orts. Purine derivatives (allantoin and uric acid) in urine were determined according to Chen and Gomes (1992). Uric acid was determined using a commercial kit (LABTEST, Lagoa Santa, MG, Brazil), after xanthine and hypoxanthine were converted to uric acid with xanthine oxidase. Thus, the uric acid values were the sum of uric acid, xanthine and hypoxanthine and the total purine derivatives (PD) were the sum of uric acid and allantoin.

Intake of compounds (DM, ash, OM, $\mathrm{N}$, and NDF) was calculated by mass difference between offered feed and orts. Apparent digestibility of compounds was calculated as \{[intake $(\mathrm{g} / \mathrm{d})$ ] - excretion $(\mathrm{g} / \mathrm{d})] /$ intake $(\mathrm{g} / \mathrm{d})\} \times 100$. True digestibility of OM was estimated considering that neutral detergent soluble fractions of the feces are from endogenous origin and only the NDF fraction of feces is originated from feed (Van Soest, 1994) as follows: [OM intake $(\mathrm{g} / \mathrm{d})$ - fecal NDF (g/d)] / OM intake $(\mathrm{g} / \mathrm{d})$. 
The number of absorbed purines ( $X$, $\mathrm{mmol} / \mathrm{d}$ ) corresponding to the amount of PD excreted ( $Y, \mathrm{mmol} / \mathrm{d}$, considering $158 \mathrm{mg} / \mathrm{mmol}$ of allantoin and $168 \mathrm{mg} / \mathrm{mmol}$ of uric acid), was calculated from the relationship derived by CHEN \& GOMES (1992): $Y=0.84 X+\left(0.150 B W^{0.75} \mathrm{e}^{-0.25 X}\right)$

The calculation of $X$ based on the value of $Y$ was made using the iterative process of NewtonRaphson as:

$X_{(\mathrm{n}+1)}=X_{\mathrm{n}}-\left[\left(\left(0.84 X+\left(0.150 B W^{0.75} \mathrm{e}^{-0.25 X}\right)\right)-Y\right) /\right.$ $\left.\left(0.84-\left(0.038 B W^{0.75} \mathrm{e}^{-0.25 x}\right)\right)\right]$ estimated as:

The supply of microbial $\mathrm{N}(\mathrm{Nm})$ was $\mathrm{Nm}(\mathrm{g} / \mathrm{d})=70 X /(0.116 \times 0.83 \times 1000)=0.727 X$ assuming a digestibility of the microbial purines of 0.83 , an $\mathrm{N}$ content in the purines of $70 \mathrm{mg} / \mathrm{mmol}$ and a ratio of purine $\mathrm{N} /$ microbial $\mathrm{N}$ of 0.116 (CHEN \& GOMES, 1992).

The Efficiency of Microbial Protein Synthesis (EMPS) was calculated by the relation between microbial $\mathrm{N}$ produced and $\mathrm{OM}$ ingested. The Efficiency of N Use (ENU) for microbial protein synthesis was considered as the relation between produced microbial $\mathrm{N}$ and $\mathrm{N}$ ingested.

The $\mathrm{N}$ retention was calculated by the difference between $\mathrm{N}$ ingested and $\mathrm{N}$ excreted. The efficiency of $\mathrm{N}$ use by the animal was determined by the relation between $\mathrm{N}$ retained and $\mathrm{N}$ ingested.
Data were analyzed using the MIXED procedure of SAS software (SAS ${ }^{\circledR}$ Institute Inc., Cary, NC, EUA, 2009), according to the model:

$Y_{i j k}=\mu+A_{i}+P_{j}+T_{k}+e_{i j k}$ where $Y_{i j k l}=$ dependent variable; $\mu=$ mean of observations; $A_{i}=$ random effect of animals; $P_{j}=$ random effect of experimental periods; $T_{k}=$ fixed effects of treatments; $e_{i j k}=$ residual error. The effects of inclusion level of SPF on TMR were tested by orthogonal polynomial contrast, considering linear and quadratic effects. Data are presented as adjusted means (LSMEANS). P-values $\leq 0.05$ are considered significant and $>0.05$ and $\leq 0.10$ are considered as a tendency.

\section{RESULTS}

When the inclusion of SPF exceeded $66 \%$, there was a reduction in NDF consumption (Table 3 ). The $0 \%$ and $33 \%$ groups had lower NDF intake than the $66 \%$ and $100 \%$ groups. In addition, there was a linear effect $(P<0.001)$ according to the increase of the inclusion of SPF, was observed a decreased in NDF intake. There was a trend $(P=0.07)$ of effect of treatments on $\mathrm{CP}$ intake with a significant linear effect $(P=0.03)$. Contradictory to NDF intake, the higher the inclusion of SPF, the greater $\mathrm{CP}$ intake.

Dry matter $(\mathrm{DM})$ and organic matter $(\mathrm{OM})$ intake remained constant in both treatments $(P=0.62$

Table 3 - Intake, total tract digestibility of dry matter (DM), organic matter (OM), crude protein (CP) and neutral detergent fiber (NDF) in sheep receiving different replacement levels of ground corn by sweet potato flour as energetic concentrate. $P$-value $\leq 0.05$ are considered significant and $P$-value $\leq 0.10$ are considered as a tendency.

\begin{tabular}{|c|c|c|c|c|c|c|c|c|}
\hline \multirow[b]{2}{*}{ Item } & \multicolumn{4}{|c|}{-------------------'Treatments ${ }^{1}----------------$} & \multirow[t]{2}{*}{ SEM } & \multicolumn{3}{|c|}{-------------------- $P$-value-------------------. } \\
\hline & $0 \%$ & $33 \%$ & $66 \%$ & $100 \%$ & & Treatments & Linear & Quadratic \\
\hline \multicolumn{9}{|c|}{ 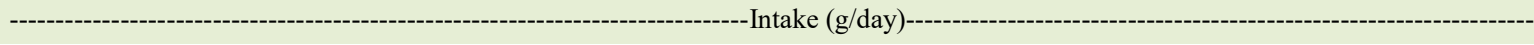 } \\
\hline DM & 840 & 859 & 832 & 857 & 80.5 & 0.621 & 0.756 & 0.858 \\
\hline OM & 774 & 788 & 758 & 788 & 71.4 & 0.323 & 0.831 & 0.543 \\
\hline $\mathrm{CP}$ & 149 & 145 & 153 & 164 & 16.6 & 0.075 & 0.032 & 0.166 \\
\hline NDF & $318^{a}$ & $304^{\mathrm{a}}$ & $263^{b}$ & $253^{b}$ & 31.1 & 0.046 & $<0.001$ & 0.791 \\
\hline \multicolumn{9}{|c|}{ - } \\
\hline DM & 74.7 & 75.5 & 75.4 & 75.9 & 2.91 & 0.944 & 0.592 & 0.920 \\
\hline $\mathrm{OM}$ & 75.4 & 76.0 & 76.4 & 76.7 & 2.9 & 0.918 & 0.477 & 0.936 \\
\hline $\mathrm{CP}$ & 75.5 & 72.2 & 76.8 & 74.9 & 3.9 & 0.386 & 0.735 & 0.733 \\
\hline NDF & 60.6 & 62.2 & 56.4 & 56.7 & 4.2 & 0.345 & 0.158 & 0.837 \\
\hline True digestibility of $\mathrm{OM}^{2}(\%)$ & 83.8 & 85.3 & 85.0 & 86.1 & 1.7 & 0.367 & 0.128 & 0.825 \\
\hline
\end{tabular}

${ }^{1}$ Treatments: levels of replacement of ground corn by sweet potato flour as energetic concentrate.

${ }^{2}$ True digestibility of OM: [OM intake (g/d) - fecal NDF (g/d)] / OM intake (g/d). SEM: standard error of the mean. 
and $P=0.32$, respectively). Apparent digestibility of $\mathrm{DM}(P=0.94), \mathrm{OM}(P=0.91), \mathrm{CP}(P=0.38)$ and, NDF $(P=0.34)$ as well as true digestibility of OM $(P$ $=0.36)$ did not present differences by increasing SPF inclusion on TMR.

There was a trend $(P=0.07)$ for treatment effects in $\mathrm{N}$ intake (Table 4$)$, with a significant linear effect $(P=0.03)$. As an increase in CP intake was observed, a linear increase in $\mathrm{N}$ intake was expected as the inclusion of SPF in the diet increased. The other parameters as urine $\mathrm{N}$ excretion $(P=0.91)$ and feces $\mathrm{N}$ excretion $(P=0.16)$ were not affected by the replacement of ground corn by SPF. Moreover, there was no effect on $\mathrm{N}$ retention $(P=0.43)$ and on efficiency of $\mathrm{N}$ use $(P=0.69)$.

Despite having changes in NDF intake and a tendency for $\mathrm{CP}$ intake, there was no effect on microbial protein parameters. Microbial protein synthesis did not present any differences $(P=0.96)$ between treatments (Table 5), as well as the EMPS ( $P$ $=0.98)$ and the ENU for microbial protein synthesis $(P=0.95)$.

\section{DISCUSSION}

Results confirmed the hypothesis that SPF can replace ground corn at any level, without compromising digestibility or proteic metabolism, if it is included urea or another nitrogen source capable of supplying the protein difference between corn and sweet potato. Considering the differences in the ruminal degradation rate of corn and SPF in a previous in vitro study (DEMARCO et al., 2020), it would be expected alterations in NDF digestibility. It is known that the inclusion of highly degradable carbohydrates in the diet can lead to a decrease in ruminal $\mathrm{pH}$, and its consequent decrease in the fibrous fraction of the diet. A decrease in fiber digestibility may be caused by reduced microbial adhesion to particles or by fibrolytic bacteria death due to acid accumulation in intracellular medium (RUSSELL \& WILSON, 1996).

When ruminal $\mathrm{pH}$ is below 6 , fibrolytic activity becomes insignificant (HU et al., 2005). LUO et al. (2017) reported a significant decrease in NDF digestibility in animals fed with carbohydrates highly degradable on rumen. Thus, concentrate fraction of the diet presents an important role in rumen environment and, by consequence, in digestibility. However, this study did not confirm any changes in this parameter, suggesting that there were no major changes in ruminal $\mathrm{pH}$, even at the highest level of SPF inclusion.

In the present study; although, there was not observed any changes in NDF digestibility in the lambs supplemented with SPF, there was a linear decrease in NDF intake by increasing SPF inclusion in the diet. As observed in table 1, sweet potato had less NDF than corn and this leads to decrease in NDF total in diets which increased the amount of sweet potato; and consequently, NDF intake decreased as the levels of replacement of sweet potato flour increases.

Nonfibrous carbohydrates supplementation is considered a good strategy to increase energy intake. However, JOHNSON (1976) reports that this type of management may promote competition between amylolytic and fibrolytic bacteria, mainly by $\mathrm{N}$. In this case, cellulolytic bacteria with slower growth would be prejudiced, which may reduce fiber

Table 4 - $\mathrm{N}$ Intake, $\mathrm{N}$ retention, and efficiency of $\mathrm{N}$ use by sheep receiving different replacement levels of ground corn by sweet potato flour as an energetic concentrate. $P$-value $\leq 0.05$ is considered significant and $P$-value $\leq 0.10$ are considered as a tendency.

\begin{tabular}{|c|c|c|c|c|c|c|c|c|}
\hline \multirow[b]{2}{*}{ Item } & \multicolumn{4}{|c|}{ 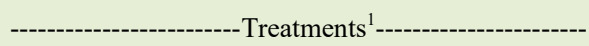 } & \multirow[t]{2}{*}{ SEM } & \multicolumn{3}{|c|}{---------------------P-value-------------------. } \\
\hline & $0 \%$ & $33 \%$ & $66 \%$ & $100 \%$ & & Treatments & Linear & Quadratic \\
\hline Intake (g/day) & 23.9 & 23.2 & 24.6 & 26.4 & 2.65 & 0.071 & 0.034 & 0.162 \\
\hline \multicolumn{9}{|c|}{ 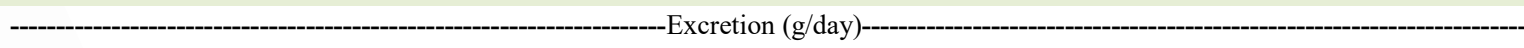 } \\
\hline Urine & 11.1 & 10.8 & 11.3 & 11.5 & 1.80 & 0.912 & 0.577 & 0.744 \\
\hline Feces & 5.85 & 6.49 & 5.59 & 6.97 & 1.21 & 0.169 & 0.226 & 0.426 \\
\hline Retention (g/day) & 6.95 & 5.85 & 7.51 & 7.86 & 1.18 & 0.438 & 0.291 & 0.455 \\
\hline $\mathrm{ENU}^{2}$ & 0.311 & 0.267 & 0.324 & 0.323 & 0.074 & 0.694 & 0.611 & 0.601 \\
\hline
\end{tabular}

${ }^{1}$ Treatments: levels of replacement of ground corn by sweet potato flour as energetic concentrate.

${ }^{2}$ Efficiency of $\mathrm{N}$ use by the animal ( $\mathrm{g}$ on retained $\mathrm{N} / \mathrm{g}$ of $\mathrm{N}$ ingested).

SEM: standard error of the mean. 
Table 5 - Microbial protein synthesis, efficiency of microbial protein synthesis and efficiency of $\mathrm{N}$ use for microbial protein synthesis by sheep receiving different replacement levels of ground corn by sweet potato flour as an energetic concentrate. $P$-value $\leq 0.05$ is considered significant and $P$-value $\leq 0.10$ is considered as a tendency.

\begin{tabular}{|c|c|c|c|c|c|c|c|c|}
\hline \multirow[b]{2}{*}{ Item } & \multicolumn{4}{|c|}{ 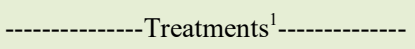 } & \multirow[t]{2}{*}{ SEM } & \multicolumn{3}{|c|}{--------------------P-value---------------- } \\
\hline & $0 \%$ & $33 \%$ & $66 \%$ & $100 \%$ & & Treatments & Linear & Quadratic \\
\hline Microbial protein synthesis ${ }^{2}$ & 10.8 & 11.1 & 11.0 & 11.5 & 2.07 & 0.961 & 0.644 & 0.937 \\
\hline EMPS $^{3}$ & 18.3 & 18.1 & 18.3 & 18.8 & 2.86 & 0.983 & 0.782 & 0.785 \\
\hline $\mathrm{ENU}^{4}$ & 0.45 & 0.46 & 0.43 & 0.43 & 0.03 & 0.958 & 0.693 & 0.875 \\
\hline
\end{tabular}

${ }^{1}$ Treatments: levels of replacement of ground corn by sweet potato flour as energetic concentrate.

${ }^{2} \mathrm{~g}$ of produced microbial N/day.

${ }^{3}$ Efficiency of microbial protein synthesis ( $\mathrm{g}$ of produced microbial N/kg of degradable OM ingested).

${ }^{4}$ Efficiency of $\mathrm{N}$ use for microbial protein synthesis ( $\mathrm{g}$ of produced microbial $\mathrm{N} / \mathrm{g}$ of $\mathrm{N}$ ingested).

SEM: standard error of the mean.

digestibility and, by consequence, fiber intake too. In fact, KOZLOSKI et al. (2006), working with lambs receiving dwarf elephant grass hay (Pennisetum purpureum Schum. cv. Mott) and supplemented with different levels of corn grain observed a substitution in hay intake in the greater energetic inclusions. In this case, the authors associated the decrease in NDF intake with the decreased fiber digestibility.

Another possible explanation for the decrease in fiber intake by increasing highly degradable NFC intake can be found at comparing the quality of the NDF of the corn with the NDF found in the sweet potato. Factors as amylopectin, amylose, presence of protein matrix and its relationship with starch digestion were already discussed in a study by DEMARCO et al. (2020).

A higher starch degradability in the rumen is also associated to a higher DM total tract digestibility (LARSEN et al., 2009) since this feed could increase bacteria growth stimulating digestive processes due to a higher bacterial increment (HILTNER \& DEHORITY, 1983). However, this premiss was not confirmed by the present study. Even on the highest inclusion levels of SPF, DM apparent digestibility did not change, remaining within the expected values for diets composed of fiber: concentrate ratio of 60:40. The same tendency was observed don CP apparent digestibility and OM true digestibility and kept similar among treatments.

Rumen degradability of $\mathrm{CP}$ is highly dependent on ruminal $\mathrm{pH}$ and the type of feed that makes up the diet (BACH et al., 2005). Although, amylolytic bacteria have higher proteolytic activity than cellulolytic bacteria (WU et al., 2006; RAMOS et al., 2009), it seems that the higher bacterial increment caused by the inclusion of more degradable carbohydrates may limit the amount of $\mathrm{N}$ available for microbial protein synthesis. This may explain the tendency of linear increase on CP intake presented by the animals of this study. Due to a higher need of CP for microbial protein synthesis, they chose to eat first the concentrate feedstuff. Microbial protein synthesis in the rumen is dependent on the availability of degradable protein and carbohydrates (CHUMPAWADEE et al., 2006), and the magnitude of this process is influenced by the synchronicity between nitrogen source degradability and energy source degradability (GEHMAN et al., 2006).

The EMPS is influenced by several factors as diet composition, rumen $\mathrm{pH}$ and species of bacteria in the rumen (CATON et al., 1993). EMPS values reported in this study were considerably lower than those found by (PATHAK, 2008), which reported values of $28 \mathrm{~g}$ of $\mathrm{N}$ produced per $1 \mathrm{~kg}$ of degradable $\mathrm{OM}$ ingested in animals receiving mixed diets. Although, it is a widely used concept, EMPS do not estimate how many units of $\mathrm{N}$ the bacteria are able to capture per unit of available energy in the rumen (BACH et al., 2005). As an alternative, values of the ENU for microbial protein synthesis may be used. BACH et al. (2005) affirmed that microbial protein synthesis is optimal when EMPS is $29 \mathrm{~g}$ of microbial $\mathrm{N}$ produced per $1 \mathrm{~kg}$ of degradable $\mathrm{OM}$ ingested, and the ENU is $69 \%$. Although, the values reported by the present research are out of the ideal reported by cited authors (mean EMPS $=18.4$ and mean $\mathrm{ENU}=44 \%$ ), the absence of significant differences among the treatments and as the diet met 
the nutritional requirements, it suggested that ground corn replacement by SPF can be made without any prejudice to the animal proteic metabolism.

BRODERICK (2003) using lactating cows fed with crescent levels of crude protein, reporting a linear increase in fecal and urinary $\mathrm{N}$ excretion, related to a linear increase in CP intake. TAMMINGA (1996) relates that manipulate efficiency of $\mathrm{N}$ use by the animal is an important strategy to reduce $\mathrm{N}$ losses. In the present study; although, CP intake has increased linearly with increasing levels of SPF, there was no increase in fecal and urinary $\mathrm{N}$ excretion.

The sweet potato as a source of energetic food is used in the diet of high starch ruminants, being a tuber adapted to the soil and climate conditions of tropical and subtropical zone (ARAÚJO et al., 2015). During the production process of sweet potatoes, a certain amount is discarded in the fields, due to factors such as shape and size, not being directed to human market. The sweet potato tillage that is not destinated for the human food remains over the soil after harvest, which might develop fungus and damage the soil. Thus, the use of this crop residue for ruminant feeding presents an environmental and economic sustainability for use in certain ruminant production systems.

\section{CONCLUSION}

Ground corn replacement by SPF on sheep receiving mixed diets can be done at any level without compromising DM intake and digestibility, microbial protein synthesis or $\mathrm{N}$ retention by metabolism, if it is included urea or another nitrogen source to equalize crude protein difference between corn and sweet potato.

\section{ACKNOWLEDGEMENTS}

This study was funded in part by the Coordenação de Aperfeiçoamento de Pessoal de Nível Superior - Brasil (CAPES) Finance Code 001 and Cooperativa Sicredi.

\section{DECLARATION OF CONFLICT OF INTEREST}

The authors declare no conflict of interest. The founding sponsors had no role in the design of the study, in the collection, analyses, or interpretation of data, in the writing of the manuscript and in the decision to publish the results.

\section{AUTHORS' CONTRIBUTIONS}

All authors contributed equally to the design and writing of the manuscript. All authors critically reviewed the manuscript and approved the final version.

\section{REFERENCES}

ARAÚJO, C. S. P. et al. Desidratação de batata-doce para fabricação de farinha, Agropecuária Científica no Semiárido, v.11, p.33-41. 2015. Available from: <http://revistas.ufcg.edu.br/ acsa/index.php/ACSA/article/view/687>. Accessed: Mar. 3, 2020. doi: 10.30969/acsa.v11i4.687

Association of Official Analytical Chemists AOAC. Official Methods of Analysis,. 1997. 17th ed. Gaithersburg, MD, USA.

$\mathrm{BACH}, \mathrm{A}$. et al. Nitrogen metabolism in the rumen, Journal of Dairy Science, v.88, p.9-21. 2005. Avaliable from: $<$ https://doi. org/10.3168/jds.S0022-0302(05)73133-7>. Accessed: Mar. 10, 2020. doi: 10.3168/jds.S0022-0302(05)73133-7.

BRODERICK, G. A. Effects of varying dietary protein and energy levels on the production of lactating dairy cows, Journal of Dairy Science, v.86, p.1370-1381, 2003. Available from: $<$ https://doi. org/10.3168/jds.S0022-0302(03)73721-7>. Accessed: Apr. 3, 2020. doi: 10.3168/jds.S0022-0302(03)73721-7.

CATON, J. S.; DHUYVETTER, D. V. Influence of energy supplementation on grazing ruminants: requirements and responses, Journal of Dairy Science, v.75, p.533-542, 1997. Available from: $\quad<$ https://www.researchgate.net/publication/14158958 Influence of Energy_Supplementation on Grazing_Ruminants Requirements_and_Responses $>$. Accessed: Feb. 16, 2020. doi: $10.2527 / 1997.752533 x$

CATON, J. S. et al. Influence of Aspergillus oryzae fermentation extract on forage intake, site of digestion, in situ degradability, and duodenal amino acid flow in steers grazing cool-season pasture, Journal of Dairy Science, v.71, p.779-787, 1993. Available from: $<$ https://academic.oup.com/jas/article-abstract/71/3/779/4716778>. Accessed: Mar. 16, 2020. doi: 10.2527/1993.713779x.

CHEN, X. B.; GOMES, M. J. Estimation of microbial protein supply to sheep and cattle based on urinary excretion of purine derivatives: an overview of the technical details, Aberdeen: Rowett Research Institute, 21p. 1992. Available from: <https:// www.researchgate.net/publication/265323654 Estimation of Microbial_Protein_Supply_to_Sheep_and_Cattle_Based_on_ Urinary_Excretion_of_Purine_Derivatives_-_An_Overview_of Technical Details $>$. Accessed: Mar. 19, 2020.

CHUMPAWADEE, S. et al. Effects of synchronizing the rate of dietary energy and nitrogen release on ruminal fermentation, microbial protein synthesis, blood urea nitrogen and nutrient digestibility in beef cattle, Asian-Austrailian Journal of Animal Science, v.19, p.181-188, 2006. Available from: <https://doi. org/10.5713/ajas.2006.181>. Accessed: Mar. 24, 2020. doi: 10.5713/ajas.2006.181

DECKARDT, K. et al. Peculiarities of enhancing resistant starch in ruminants using chemical methods: opportunities and challenges, Nutrients, v.5, p.1970-1988. 2013. Available from: < https://www. ncbi.nlm.nih.gov/pmc/articles/PMC3725487/>. Accessed: Feb. 22, 2020. doi: $10.3390 /$ nu5061970.

DEMARCO, C. F. et al. In vitro fermentation of diets containing sweet potato flour as a substitute for corn in diets for ruminants. Ciência Rural, Santa Maria, v.50, n.8, 2020. Available from $<$ http: //www.scielo.br/scielo.php?script=sci_arttext\&pid=S010384782020000800651\&lng=en \&nrm=iso $>$. Accessed: 26 Jan. 2021. Epub Jun. 19, 2020. doi: 10.1590/0103-8478cr20181055. 
FARENZENA, R. et al. Minimum length of the adaptation and collection period in digestibility trials with sheep fed ad libitum only forage or forage plus concentrate, Journal of Animal Physiology and Animal Nutrition, v.101, p.1057-1066. 2017. Available from: <https://pubmed.ncbi.nlm.nih.gov/27453214/>. Accessed: Feb. 24, 2020. doi: 10.1111/jpn.12550.

GEHMAN, A. M. The effect of carbohydrate source on nitrogen capture in dairy cows on pasture, Journal of Dairy Science, vol.89, p.2659-2667. 2006. Available from: <https://doi.org/10.3168/jds. S0022-0302(06)72342-6>. Accessed: Mar. 24, 2020. doi: 10.3168/ jds.S0022-0302(06)72342-6.

GÓMEZ, L. M. et al. Starch in ruminant diets: a review, Revista Colombiana de Ciencias Pecuarias, v.29, p.77-90, 2016 Available from: $<$ http://dx.doi.org/10.17533/udea.rccp.v29n2a01>. Accessed: Mar. 03, 2020. doi: 10.17533/udea.rccp.v29n2a01.

HILTNER, P.; DEHORITY, B. A. Effect of soluble carbohydrates on digestion of cellulose by pure cultures of rumen bacteria, Applied and Environment Microbiology, v.46, p.642-648. 1983. Available from: <https://www.ncbi.nlm.nih.gov/pmc/articles/ PMC239329/>. Accessed: Mar. 08, 2020.

$\mathrm{HU}, \mathrm{Z}$. H. et al. Influence of particle size and $\mathrm{pH}$ on anaerobic degradation of cellulose by ruminal microbes, International Biodeterioration and Biodegradation, v.55, p.233-238. 2005. Available from: <https://doi.org/10.1016/j.ibiod.2005.02.002>. Accessed: Mar. 14, 2020. doi: 10.1016/j.ibiod.2005.02.002.

JOHNSON, R. R. Influence of carbohydrate solubility on nonprotein nitrogen utilization in the ruminant, Journal of Animal Science, v.43, p.184-191 1976. Available from: <https://doi. org/10.2527/jas1976.431184x>. Accessed: Mar. 24, 2020. doi: $10.2527 /$ jas $1976.431184 x$.

KOZLOSKI, G. V. et al. Intake and digestion by lambs of dwarf elephant grass (pennisetum purpureum schum. cv. mott) hay or hay supplemented with urea and different levels of cracked corn grain, Animal Feed Science and Technology, v.125, p.111-122. 2006. Available from: < https://europepmc.org/article/agr/ind43779301>. Accessed: Feb. 20, 2020. doi: 10.1016/j.anifeedsci.2005.05.021.

LARSEN, M. et al. Digestion site of starch from cereals and legumes in lactating dairy cows, Animal Feed Science and Technology, v.153, p.237-248. 2009. Available from: $<$ https://doi. org/10.1016/j.anifeedsci.2009.06.017>. Accessed: Mar. 24, 2020. doi: 10.1016/j.anifeedsci.2009.06.017.

LUO, G. et al. Effects of ruminally degradable starch levels on performance, nitrogen balance, and nutrient digestibility in dairy cows fed low corn-based starch diets, Asian-Australian Journal of Animal Science, v.30, p.653-659. 2017. Available from: $<$ https://www.ncbi.nlm.nih.gov/pmc/articles/PMC5411824/>. Accessed: Mar. 11, 2020. doi: 10.5713/ajas.16.0371.

NRC - National Research Council, 2007. Nutrient Requirements of small ruminants: sheep, goats, cervids, and new world camelids. 7th ed., (National Academy Press), 347p. Available from: <https://www.nap.edu/catalog/11654/nutrient-requirementsof-small-ruminants-sheep-goats-cervids-and-new $>$. Accessed: Mar. 11, 2020.

MERTENS, D. R. Gravimetric determination of amylase-treated neutral detergent fiber in feeds with refluxing in beaker or crucibles: collaborative study, Journal of AOAC International, v.85, n.6, p.1217- 1240. 2002. Available from: <https://pubmed. ncbi.nlm.nih.gov/12477183/>. Accessed: Mar. 11, 2020.

PASSETTI, R. A. C. et al. Intensive dairy farming systems from Holland and brazil: swot analyze comparison, Acta Scientiarum Animal Science, v.38, p.439-446. 2016. Available from: $<$ https:// doi.org/10.4025/actascianimsci.v38i4.31467>. Accessed: Mar. 20, 2020. doi: 10.4025 /actascianimsci.v38i4.31467.

PATHAK, A. K. Various factors affecting microbial protein synthesis in the rumen, Veterinary World, v.1, p.186-189. 2008. Available from: <http:/www.veterinaryworld.org/2008/June/ Various $\% 20$ factors $\% 20$ affecting $\% 20$ microbial $\% 20$ protein $\% 20$ synthesis\%20in\%20the.pdf >. Accessed: Feb. 17, 2020.

RAMOS, S. et al. Microbial protein synthesis, ruminal digestion, microbial populations, and nitrogen balance in sheep fed diets varying in forage-to-concentrate ratio and type of forage, Journal of Animal Science, v.87, p.2924-2934. 2009. Available from: $<$ https://doi.org/10.2527/jas.2009-1938>. Accessed: Mar. 24, 2020. doi: $10.2527 /$ jas.2009-1938.

ROSTAGnO, H. S. Tabelas Brasileiras para Aves e Suínos - Composição de Alimentos e Exigências Nutricionais. 3a ed. Viçosa: UFV, Departamento de Zootecnia. 2005. Available from:<https://www.agencia.cnptia.embrapa.br/Repositorio/ Tabelas+brasileiras+-+Rostagno_000gyltqvm602wx7ha0b6gs0xf zo6pk5.pdf >. Accessed: Mar. 24, 2020.

RUSSELL, J. B.; WILSON, D. B. Why are ruminal cellulolytic bacteria unable to digest cellulose at low $\mathrm{pH}$, Journal of Dairy Science, v.79, p.1503-1509. 1996. Available from: <https://doi. org/10.3168/jds.S0022-0302(96)76510-4>. Accessed: Apr. 4, 2020. doi: 10.3168/jds.S0022-0302(96)76510-4.

SANTANA, A. L.; MEIRELES, M. A. A. New starches are the trend for industry applications: a review, Food Public Health, v.4, p.229-241. 2014. Available from: <http://article.sapub. org/10.5923.j.fph.20140405.04.html>. Accessed: Mar. 21, 2020.

SENGER, C. C. D. et al. Evaluation of autoclave procedures for fibre analysis in forage and concentrate feedstuffs, Animal Feed Science and Technology, v.146, p.169-174. 2008. Available from: $<$ https://doi.org/10.1016/j.anifeedsci.2007.12.008>. Accessed: Mar. 6, 2020. doi: 10.1016/j.anifeedsci.2007.12.008.

TAMMINGA, S. A review on environmental impacts of nutritional strategies in ruminants, Journal of Animal Science, v.74, p.31123124. 1996. Available from: <https://academic.oup.com/jas/ article-abstract/74/12/3112/4624819?redirectedFrom=fulltext $>$. Accessed: Feb. 21, 2020. doi: 10.2527/1996.74123112x.

VAN SOEST, P. J. Nutritional ecology of the ruminant. 2.ed. Cornell University Press, Ithaca. 1994.

VELARDE, L. C. U.; et al., Potential role of sweet potato to improve smallholder crop-livestock production systems. International Society for Tropical Root Crops, p.1-9, 2015.

WU, G. et al. Board-invited review: intrauterine growth retardation: implications for the animal sciences, Journal of Animal Science, v.84, p.2316-2337. 2006. Available from: <https://pubmed.ncbi. nlm.nih.gov/16908634/>. Accessed: Mar. 14, 2020. doi: 10.2527/ jas.2006-156. 